\title{
Pathogenesis of Immune-Mediated Neuropathies
}

\author{
A. M. ROSTAMI \\ Department of Neurology, University of Pennsylvania School of Medicine, Philadelphia, Pennsylvania 19104
}

\begin{abstract}
A variety of peripheral neuropathies are believed to be immune-mediated. Acute inflammatory demyelinating polyneuropathy or Guillain-Barré syndrome (GBS) is the prototype of these neuropathies. GBS is characterized by acute progressive motor weakness of the extremities and of bulbar and facial musculature. Deep tendon reflexes are reduced or absent, and sensory symptoms are mild. Respiratory failure and autonomic dysfunction may be seen. The cerebrospinal fluid shows increased protein and no or very few cells. The nerve conduction velocity is slowed, and the pathology shows segmental demyelination with mononuclear cell infiltration. Studies from man and experimental animals suggest an immunologic basis for demyelination of the peripheral nerves in GBS, but the mechanism is not well understood. Experimental allergic neuritis, an animal model of GBS, is induced in laboratory animals by immunization with myelin $P_{2}$ protein, some peptides of $P_{2}$ protein, and galactocerebroside. The animals develop weakness and show electrophysiologic and pathologic features similar to GBS. $\mathbf{P}_{2^{-}}$ reactive $T$ cells and antigalactocerebroside antisera can adoptively transfer experimental allergic neuritis. Various antibodies to peripheral nerve myelin and circulating immune complexes have been found in patients with GBS. The target antigen(s) for these antibodies are not well understood, but neutral glycolipids cross-reactive with Forssman antigen and gangliosides are possible candidates. The mainstay of therapy is the management of the paralyzed patient. Steroids are ineffective. Plasmapheresis, especially early in the course of the disease, can shorten the duration of paralysis and intubation. Results from a multicenter study in the Netherlands demonstrate the efficacy of high-dose immune globulin therapy in GBS. In this review, Guillain-Barré syndrome as a putative immune-mediated neuropathy is discussed in detail. Chronic inflammatory demyelinating polyneuropathy, neuropathies associated with paraproteinemias, AIDS, and Lyme disease are discussed briefly. Neuropathies with features of inflammation secondary to other infections and collagen vascular disorders are not the subject of this review. (Pediatr Res 33 (Suppl): S90-S94, 1993)
\end{abstract}

\section{Abbreviations}

CIDP, chronic inflammatory demyelinating polyneuropathy

CMV, cytomegalovirus

CSF, cerebrospinal fluid

EAN, experimental allergic neuritis

EBV, Epstein-Barr virus

GBS, Guillain-Barré syndrome

HIV, human immunodeficiency virus

Correspondence: A. M. Rostami, M.D., Ph.D., Department of Neurology, Hospital of the University of Pennsylvania, 3400 Spruce Street, Philadelphia, PA 19104.

Supported in part by Grants NS08075 and AR39489 from the National Institutes of Health.
IVIG, intravenous immune globulin

\section{GUILLAIN-BARRÉ SYNDROME}

Clinical aspects. GBS is a distinct clinical entity characterized by acute progressive motor weakness of the extremities and of bulbar and facial musculature. Deep tendon reflexes are reduced or absent and sensory symptoms are mild.

The CSF shows albuminocytologic dissociation with increased protein and no or very few cells. Electrophysiologically, the disease has features of demyelination and pathology shows segmental demyelination with mononuclear cell infiltration.

An ad hoc National Institute of Neurological Disorders and Stroke committee produced guidelines for the diagnosis of GBS (1). These criteria are somewhat restrictive and exclude certain nosologic entities such as: 1) Miller Fisher syndrome of ophthalmoplegia, ataxia, and areflexia; 2) sensory loss and areflexia; 3 ) polyneuritis cranialis; and 4) pandysautonomia. These disorders are generally believed to be "variants" of GBS (1).

Motor weakness usually develops rapidly. More than $90 \%$ of patients with GBS cease to progress within $4 \mathrm{wk}$ into the disease. Recovery usually begins 2 to 4 wk after the cessation of progression but may be delayed for months (1). Many patients are left with a residual deficit after 1 y (2). In another study, the median time of recovery to independent walking was $85 \mathrm{~d}$, and for those on a respirator it was $169 \mathrm{~d}$ (3). Autonomic dysfunction such as cardiac arrhythmias, tachycardia, postural hypotension, and hypertension are seen and at times could be fatal. Conditions such as hexacarbon abuse, porphyria, diphtheria, lead poisoning, botulism, toxic neuropathies, hysteria, tic paralysis, and poliomyelitis occasionally may be confused with GBS and need to be ruled out.

Epidemiology. The incidence of GBS varies from 0.6 to $1.9 /$ 100000 per year (3). The disease is widely distributed throughout the world. Children and adults of both sexes are affected. There seems to be a bimodal distribution of patients, with the major peak in patients aged 16 to $25 \mathrm{y}$ and a smaller peak in those aged 45 to $60 \mathrm{y}$. Males and Caucasians seem to be most susceptible (4). GBS was the most likely etiology $(15 \%)$ in 162 cases of neuropathy evaluated in the Children's Hospital of Philadelphia (5).

In a survey of more than 1000 cases of GBS, approximately $66 \%$ had had a viral-like illness, mainly in the respiratory and gastrointestinal tracts, within $8 \mathrm{wk}$ of the onset of GBS and about $90 \%$ had had a viral-like illness within 1 mo of expressing GBS symptoms. Five percent had a previous surgical procedure and $4.5 \%$ had received vaccinations. A cluster of GBS occurred in the United States in 1976-1977, after vaccination with A/New Jersey influenza. No similar outbreak occurred in a military population receiving the same vaccine $(3,4)$.

Antecedent infections in GBS can be viral, bacterial, or parasitic. CMV and EBV are the most common viral infections reported to be associated with GBS. High levels of IgM antibodies 
to CMV are seen in $10-15 \%$ of GBS cases. Ten percent have antibodies to EBV and 5\% have serologic evidence of $\mathrm{MyCO}$ plasma pneumoniae (6). An interesting association between GBS and Campylobacter jejuni has been reported. In one study, $38 \%$ of 56 consecutive GBS patients in an Australian hospital had positive serology for $C$. jejuni. None of the 57 normal patients and patients with other neurologic diseases had evidence of $C$. jejuni infection (7). Others have found a lower percentage (18\%) of GBS patients to have the antibody to these bacteria (8). GBSlike syndromes are also seen in patients with AIDS and Lyme disease $(9,10)$.

Pathogenesis. There is strong evidence that demyelination in the peripheral nerves and consequent neurologic deficit in GBS are the result of an immunologic attack on the peripheral nervous system myelin or possibly Schwann cells. This evidence is derived from immunologic and pathologic studies on the patients with GBS and data from an animal model of the disease, EAN.

EAN is induced in various laboratory animals by immunization with whole nerve, peripheral nervous system myelin, one of the myelin basic proteins $\left(\mathrm{P}_{2}\right)$, some peptides of $\mathrm{P}_{2}$ protein (1114), and galactocerebroside (15). Recently, a synthetic peptide corresponding to 53-78 amino acid residues of $\mathrm{P}_{2}$ protein was also shown to produce severe EAN in Lewis rats (16). About 2 wk after immunization, the animals develop weight loss, flaccid tail, ataxia, and paraplegia, or, in severe cases, tetraplegia. The majority of the animals recover from the disease in about $1 \mathrm{wk}$.

Starting $10 \mathrm{~d}$ after immunization, there is electrophysiologic evidence of slowing in the sciatic motor conduction, which is slowest about $24 \mathrm{~d}$ postimmunization. There is dispersion of action potentials, conduction block, and prolongation of F-wave latencies, which are the electrophysiologic hallmarks of demyelination (14). In rats, the pathologic changes of EAN consist of multifocal areas of primary demyelination in dorsal root ganglia, roots, and sciatic nerves. Demyelinative lesions are often associated with axonal degeneration. Large diameter, thinly myelinated axons indicative of recent remyelination are seen. Multifocal mononuclear cell infiltration frequently occurs in a perivenular distribution, mainly in the areas of demyelination. $T$ cells of helper and suppressor phenotype, as well as B cells and macrophages, are seen in the involved nerves (14-16). In whole nerve and $\mathrm{P}_{2}$-induced EAN, in early stages of the disease, myelin vesiculation and endoneurial edema can be observed in the absence of mononuclear cell contact (17). EAN in Lewis rats can be transferred with $P_{2}$-reactive $T$ cells $(18-20)$. $T$ cells reactive to the peptide 53-78 of bovine $\mathrm{P}_{2}$ protein also can transfer EAN (21). These observations provide direct evidence that $P_{2}$-induced EAN is a cell-mediated immune phenomenon.

Schwann cells from newborn rats have MHC class II antigens on their surface and present antigen to syngeneic myelin basic protein reactive $T$ cells (22). However, cells other than Schwann cells, and most likely macrophages, play an essential role as antigen-presenting cells in the peripheral nerves, as is shown by the successful adoptive transfer of EAN with $\mathrm{P}_{2}$-reactive $T$ cells of Lewis origin into DA rats that have been lethally irradiated and reconstituted with (Lewis $\times \mathrm{DA}$ ) F1 bone marrow cell (23). Double-label experiments using antibodies to $\mathrm{S} 100$ protein of Schwann cells and Ia molecules have demonstrated that Iapositive cells are not Schwann cells and are most likely $E_{1_{1}}$ positive macrophages (24). Others found the same results with different techniques (25). Macrophages are believed to be the cells responsible for destruction of myelin sheath either directly or by secreting proteases and inflammatory mediators (26).

EAN induced by galactocerebroside in rabbits has a distinct pathology compared with myelin or $\mathrm{P}_{2}$-induced EAN. Perivenular infiltration of small lymphocytes is not seen, but macrophages insinuate themselves between the myelin lamellae and phagocytize them. Serum showing high antigalactocerebroside antibody titer from rabbits immunized with galactocerebroside can demyelinate rat peripheral nerve when injected intraneurally.
This form of EAN is clearly mediated through antibodies, and galactocerebroside seems to be the target antigen $(15,27,28)$.

Based on the observation that the herpes viruses, CMV and EBV, are associated with GBS, viruses have been thought to be possible etiologic agents for the disorder. Indeed, for some time GBS was called acute infective polyneuritis (29). A herpes virus of birds, known as Marek's disease virus, produces a lymphoproliferative disorder in chickens. This disease can be associated with paralysis of the wings and legs in chickens and a nerve pathology similar to GBS (30). A condition similar to GBS in patients with HIV infection and high titer of antibodies to $C$. jejuni or mycoplasma is also taken as evidence that bacteria and viruses may be involved in the pathogenesis of GBS directly or indirectly through activation of elements in the immune system. To date, no conclusive evidence as to the infectious etiology of GBS is available.

The landmark work of Asbury et al. (31) on the pathology of GBS and the finding of mononuclear infiltration in the peripheral nerves in the areas of segmental demyelination similar to that of EAN focused the attention of workers in the field on the possible immunologic basis for myelin injury. A variety of immunologic abnormalities are reported in GBS. Cell-mediated immunity to $\mathrm{P}_{2}$ protein has been reported in GBS $(32,33)$ but not confirmed by others $(34,35)$. Reports that GBS peripheral blood lymphocytes can demyelinate myelinated cultures in vitro (36) cannot be taken as evidence of the cytotoxic capability of these cells due to the differences in the major histocompatibility complex of effector cells and target tissues. Lymphokines or antibodies secreted by $\mathrm{T}$ and $\mathrm{B}$ cells or nonspecific killer cell activity may explain these observations. There are reports of changes in $T$-cell subsets in the peripheral blood showing a decrease in either CD4 (T helper/inducer) or CD8 ( $T$ suppressor/cytotoxic) cells in GBS $(37,38)$, but others have reported no changes in the T-cell subsets (39). Serum IL-2 concentration is increased in GBS and correlates with the activity of the disease, suggesting an ongoing $\mathrm{T}$ cell activation and proliferation in these patients (40). Serum levels of soluble IL-2 receptors and higher proportions of peripheral blood lymphocytes expressing transferrin and IL-2 receptors (41) are also indicative of the active role of T cells in GBS. These $T$ cells can exert their action either directly or through the activation of the macrophages by helping $B$ cells to secrete autoantibodies and to produce harmful cytokines to injure the myelin sheath and/or Schwann cells. Despite these observations, no clear-cut role for $T$ cells in the pathogenesis of GBS is documented.

Antigen-presenting cells in human peripheral nerves are thought to be Schwann cells (42); however, data from EAN (see above) point to resident macrophages rather than Schwann cells being antigen-presenting cells.

Antibodies to various peripheral nerve components are represented in GBS. On the basis of the observation that antigalactocerebroside antisera can demyelinate rat peripheral nerves in vivo, antibodies to galactocerebroside have been sought in serum and CSF from patients with various demyelinating disorders, including GBS, CIDP, multiple sclerosis, and various other neurologic disorders using various assays, including RIA and ELISA. No humoral immune response to galactocerebroside in human demyelinating disorders was observed (43). Serum from acute GBS can produce demyelination when injected into the rat sciatic nerve (44). Various antibodies to peripheral nerve components and circulating immune complexes have been reported in patients with GBS $(45,46)$. Oligoclonal bands are seen in the CSF of GBS, but are usually transient, unlike multiple sclerosis. High titers of antibodies, including complement fixing antibodies to human peripheral nerve myelin, have been demonstrated in the serum of GBS patients compared with normal patients and those found in a variety of inflammatory neurologic and nonneurologic disorders. The target antigen(s) for these antibodies are not well understood, but neutral glycolipids cross-reactive with Forssman antigen (47), gangliosides (48), and sulfoglucoronyl glycolipids 
(49) have been suggested as possible candidates. These observations on the role of antibodies in GBS and EAN were the basis for the use and subsequent demonstration of efficacy of plasmapheresis in GBS.

Treatment. Although about $80 \%$ of GBS patients recover from the disease, the course of the disorder can be stormy. About $30 \%$ of patients in one study required intubation for an average of 51 $\mathrm{d}$; average hospital stay was $61 \mathrm{~d}(50)$. The mainstay of therapy is the management of paralyzed patients, which is best accomplished in intensive care units.

Plasmapheresis was found to be effective in decreasing morbidity and shortening the course of GBS. In the United States multicenter controlled study performed on 245 patients with GBS (51), the patients treated with plasmapheresis had better outcomes when compared with patients not treated with plasmapheresis in terms of time needed to improve one clinical grade, outcome at $4 \mathrm{wk}$ and $6 \mathrm{mo}$, and time when the patient could walk unaided. Plasmapheresis also reduced the number of days on the respirator. In severe cases, especially when ventilatory assistance is needed or when the patient has a rapidly progressive course, plasmapheresis is indicated. Once the decision to treat patients with plasmapheresis has been made, it should begin as early as possible.

In one randomized clinical trial of corticosteroid treatment for GBS, no beneficial effect was observed (52). Another study, using $A C T H$, reported significant reductions in duration of disease (53). A British multicenter study is underway with high-dose methylprednisone as one treatment arm. There is no conclusive evidence that azathioprine and cyclophosphamide can be of any help in GBS (54).

Results from a multicenter study in the Netherlands comparing high-dose IVIG with plasma exchange in 150 patients demonstrate a better outcome in patients receiving IVIG compared with those treated with plasma exchange. Beneficial outcome was defined as improvement in at least one grade on a sevenpoint functional scale $4 \mathrm{wk}$ after randomization (55).

\section{CIDP}

CIDP is characterized by subacute onset (usually over months) of chronic progressive, relapsing or chronic monophasic course. Maximum disability is usually reached after 6-12 mo, and peripheral nerve demyelination can be demonstrated by electrophysiology and histopathology $(56,57)$. Inflammatory cells in the nerves are less prominent than in GBS. Protein is elevated in the CSF, but no or very few cells are found. No systemic disease or serum paraproteins are present. In a large series of CIDP patients (92 cases) $(57,58), 65 \%$ had a relapsing course and $35 \%$ had a progressive monophasic course. Thirty-five percent had a history of an antecedent event, mainly infectious, with a significantly increased level of antibodies to CMV compared with controls. A good recovery was made by $73 \%$ of CIDP patients, and they became independent $(57,58)$. The exact mechanism of myelin destruction is unknown, although immune-mediated mechanisms have been postulated, and binding of IgG to the myelin sheath with the subsequent destruction of myelin segments by macrophages has been proposed. The role of cell-mediated immunity in the pathogenesis of CIDP is speculative (59). Prednisone is generally the drug of first choice. Patients not responding to prednisone or patients with a rapidly progressive course can be treated with plasmapheresis or a combination of plasmapheresis and prednisone $(54,60)$. In cases of failure with prednisone and plasmapheresis, other immunosuppressive agents such as azathioprine or cyclophosphamide and IVIG may be used (61).

\section{PERIPHERAL NEUROPATHIES ASSOCIATED WITH PARAPROTEINEMIA}

Peripheral neuropathy can occur in association with plasma cell dyscrasias such as multiple myeloma, Waldenstrom's mac- roglobulinemia, heavy chain disease, cryoglobulinemia, nonmalignant monoclonal gammopathy, and primary amyloidosis. Serum protein electropheresis from these patients usually shows homogenous bands of abnormal mobility called paraproteins or $\mathrm{M}$ proteins. Asymptomatic $\mathrm{M}$ proteins (not associated with malignant plasma cell dyscrasias) are common in adults (approximately $1 \%$ ) and are referred to as benign or nonmalignant monoclonal gammopathy (62). Nonmalignant IgM monoclonal gammopathy or paraproteinemia can be associated with distal symmetrical sensorimotor, purely motor, or predominantly sensory neuropathies that are usually slowly progressive. Waldenström's macroglobulinemia should be ruled out before the diagnosis of nonmalignant IgM gammopathy and neuropathy is made. In some patients, $M$ protein in the serum is shown to be directed against myelin-associated glycoprotein. Serum from other patients reacts with chondroitin sulfate or other antigens $(62,63)$. Males are predominantly affected by this disorder. Nonmalignant $\operatorname{IgG}$ and $\operatorname{IgA}$ monoclonal gammopathies can also be associated with a chronic progressive or recurrent polyneuropathy. The nerve pathology in these gammopathies is usually demyelinative, sometimes associated with axonal degeneration, and shows no significant cellular infiltration. In osteosclerotic myeloma, which is almost always associated with $\lambda$ light chains, a syndrome of polyneuropathy, organomegaly, endocrinopathy, $M$ protein, and skin changes (POEMS) has been reported (64). Plasmapheresis may be helpful in reducing $M$ proteins in the serum. By treating underlying plasma cell dyscrasia with chemotherapy and radiation therapy, the peripheral nerve deficit may improve.

There are reports of association of motor neuron-like disease and IgM paraproteinemia. In several of these amyotrophic lateral sclerosis-like patients, the IgM paraproteins bind GM1 and GD 1 b gangliosides (65). Selective degeneration of ventral roots and chromatolytic changes in the anterior horn cells have been observed. Several patients with the syndrome have improved with plasma exchange and immunosuppressive therapy (66).

\section{NEUROPATHIES ASSOCIATED WITH HIV INFECTION}

Several peripheral nerve syndromes are reported in patients with HIV infection including: 1) distal symmetrical sensorimotor neuropathy, 2) CIDP, 3) mononeuritis multiplex, 4) progressive polyradiculopathy, 5) Guillain-Barré-like acute inflammatory polyneuropathy, and 6) autonomic neuropathy. In AIDS patients, it is believed that acute inflammatory polyneuropathy, CIDP, and possibly mononeuritis multiplex have an autoimmune pathogenesis. Polyradiculopathy could be due to direct infection by CMV, herpes virus, or HIV. The pathogenesis of other types of peripheral nerve disorders in AIDS is even less understood. Plasmapheresis has been shown to be effective in AIDS-related inflammatory neuropathies $(67,68)$.

\section{NEUROPATHIES ASSOCIATED WITH LYME DISEASE}

Peripheral nerve involvements are reported in infections by the spirochete Borrelia burgdorferi (Lyme disease). Bilateral facial palsy, GBS, mononeuritis multiplex, and brachial neuritis are all seen; and the CSF of Lyme disease patients may show lymphocytic pleocytosis, oligoclonal bands, and antibody to B. burgdorferi. Sural nerve biopsy shows loss of myelinated and unmyelinated axons with perivascular infiltration. Others did not report inflammatory changes in the nerves. The pathogenesis of peripheral nerve disorders in Lyme disease is not well understood. Antibiotic therapy is generally effective in management of the peripheral nerve involvement in this disorder (68-70).

\section{REFERENCES}

1. Asbury AK 1981 Diagnostic considerations in Guillain-Barré syndrome. Ann Neurol 9(suppl):1-5

2. McKhann GM 1990 Guillain-Barré syndrome: clinical and therapeutic observations. Ann Neurol 27(suppl):S13-S16 
3. Schoenberger LD, Hurwitz ES, Katona P, Holman RC, Bregman DJ 1981 Guillain-Barré syndrome: its epidemiology and association with influenza vaccination. Ann Neurol 9(suppl):31-38

4. Hurwitz ES, Holman RC, Nelson DB, Schoenberger LB 1983 National surveillance for Guillain-Barré syndrome-January 1978-March 1979. Neurology 33:156-157

5. Sladky JT 1987 Neuropathy in childhood. Semin Neurol 7:65-75

6. Cook SD, Dowling PC, Blumberg BM 1987 Infection and autoimmunity in Guillain-Barré syndrome. Clin Neuroimmunol 17:225-240

7. Kaldor J, Speed RB 1984 Guillain-Barré syndrome and Campylobacter jejuni: a serological study. Br Med J 228:1867-1870

8. Gruenewald R, Ropper AH, Lior H, Chan J, Lee R, Molinaro VS 1991 Serologic evidence of Campylobacter jejuni/coli enteritis in patients with Guillain-Barré syndrome. Arch Neurol 48:1080-1082

9. Parry GJ 1988 Peripheral neuropathies associated with human immunodeficiency virus infection. Ann Neurol 23(suppl):S46-S53

10. Pachner AR, Steere RA 1985 The triad of neurologic manifestations of Lyme disease: meningitis, cranial neuritis, and radiculoneuritis. Neurology 35:4753

11. Waksman BH, Adams RD 1985 Allergic neuritis: an experimental disease of rabbits induced by the injection of peripheral nervous tissue and adjuvants. J Exp Med 102:213-236

12. Smith ME, Hofmann WW 1979 Experimental allergic neuritis in the Lewis rat. J Neuropathol Exp Neurol 38:377-391

13. Brostoff SW, Burnett P, Lampert P 1972 Isolation and characterization of a protein from sciatic nerve myelin responsible for experimental allergic neuritis. Nature 235:210-212

14. Rostami A, Brown MJ, Lisak RP, Sumner AJ, Zweiman B, Pleasure DE 1984 The role of myelin $\mathrm{P} 2$ protein in the production of experimental allergic neuritis. Ann Neurol 16:680-685

15. Saida T, Saida K, Silberberg DH, Brown MJ 1981 Experimental allergic neuritis induced by galactocerebroside. Ann Neurol 9(suppl):S87-S101

16. Rostami AM, Gregorian SK, Brown MJ, Pleasure DE 1990 Induction of severe experimental autoimmune neuritis with a synthetic peptide corresponding to the 53-78 amino acid sequence of the myelin $P_{2}$ protein. J Neuroimmunol 30:145-151

17. Rosen JL, Brown MJ, Hickey WF, Rostami AM 1990 Early myelin lesions in experimental allergic neuritis. Muscle Nerve 13:629-636

18. Rostami A, Burns JB, Brown MJ, Lisak RP, Pleasure DE 1983 Transfer of experimental allergic neuritis (EAN) with P2-reactive T cells. Ann Neurol 14:108(abstr)

19. Rostami A, Burns JB, Brown MJ, Rosen J, Zweiman B, Lisak RP, Pleasure DE 1985 Transfer of experimental allergic neuritis with P2-reactive $T$ cell lines. Cell Immunol 91:354-361

20. Linington C, Izumo S, Suzuki M, Uyemura K, Meyermann R, Wekerle H 1984 A permanent rat $\mathrm{T}$-cell line that mediates experimental allergic neuritis in the Lewis rat in vivo. J Immunol 133:1946-1950

21. Rostami AM, Gregorian SK 1991 Peptide 53-78 of myelin $P_{2}$ protein is a $T$ cell epitope for the induction of experimental autoimmune neuritis. Cell Immunol 132:1-8

22. Wekerle H, Schwab M, Linington C, Meyermann R 1986 Antigen presentation in the peripheral nervous system: Schwann cells present endogenous myelin autoantigens to lymphocytes. Eur J Immunol 16:1551-1557

23. Kimura H, Silvers WK, Ventura E, Honda H, Rostami AM 1989 Perivascular macrophages as the antigen-presenting cells in the peripheral nervous system. Neurology 39(suppl 1):174(abstr)

24. Rostami AM, Honda H 1991 Expression of major histocompatibility complex class II antigen in experimental allergic neuritis. Neurology 41:188(abstr)

25. Schmidt B, Stoll G, Hartung HP, Heininger K, Schafer B, Toyka KV 1990 Macrophages but not Schwann cells express la antigen in experimental autoimmune neuritis. Ann Neurol 28:70-77

26. Hart NH, Hanks DT, Mackay A 1972 Ultrastructural observations in GuillainBarré syndrome. Arch Pathol 93:552-555

27. Saida K, Sumner AJ, Saida T 1980 Antiserum-mediated demyelination: relationship between remyelination and functional recovery. Ann Neurol 8:1224

28. Stoll G, Schwendemann G, Heininger K, Kohne W, Hartung H-P, Seitz RJ, Toyka KV 1986 Relation of clinical, serological, morphological and electrophysiological findings in galactocerebroside-induced experimental allergic neuritis. J Neurol Neurosurg Psychiatry 49:258-264

29. Bradford JR, Bashford EF, Wilson JA 1919 Acute infective polyneuritis. Quart J Med 12:88-103

30. Marek J 1907 Multiple nerventzundung (polyneuritis) bei Huhnern. Dtsch Tierarztl Wochenschr 15:417

31. Asbury AK, Arnason BG, Adams RD 1969 The inflammatory lesion in idiopathic polyneuritis: its role in pathogenesis. Medicine 48:173-215

32. Abramsky O, Webb C, Teitelbaum D, Arnon R 1975 Cell-mediated immunity for neuronal antigens in idiopathic polyneuritis and myeloradiculitis. Neurology 25:1154-1159

33. Sheremata W, Colby S, Karkhansis Y, Eylar E 1975 Cellular hypersensitivity to basic myelin (P2) protein in Guillain-Barré syndrome. Can J Neurol Sci 2:87-90

34. Iqbal A, Oger J-F, Arnson BGW 1981 Cell-mediated immunity in idiopathic polyneuritis. Ann Neurol 9(suppl):65-69

35. Zweiman B, Rostami AM, Lisak RP 1983 Immune responses to P2 protein in the human inflammatory demyelinative neuropathies. Neurology 33:234237
36. Arnason BGW, Winkler GJ, Hadler NM 1969 Cell-mediated demyelination of peripheral nerve in tissue culture. Lab Invest 1:1-10

37. Lisak RP, Zweiman B, Guerrero F, Moskovitz AR 1985 Circulating T cell subsets in Guillain-Barré syndrome. J Neuroimmunol 8:93-101

38. Hughes RA, Aslan CS, Gray IA 1983 Lymphocyte subpopulations and suppressor cell activity in acute polyradiculoneuritis (Guillain-Barré syndrome). Clin Exp Immunol 51:448-454

39. Hauser SL, Ropper AH, Perlo VP, Reinherz EL, Schlossmann SF, Weiner HL 1982 T-cell subsets in human autoimmune disease. Neurology 32:13211322

40. Hartung HP, Reiners K, Schmidt B, Stoll G, Toyka KV 1991 Serum interleukin-2 concentrations in Guillain-Barré syndrome and chronic idiopathic demyelinating polyradiculoneuropathy: comparison with other neurological diseases of presumed immunopathogenesis. Ann Neurol 30:48-53

41. Hartung HP, Hughes RAC, Taylor WA, Heininger K, Reiners K, Toyka KV $1990 \mathrm{~T}$ cell activation in Guillain-Barré syndrome and in MS: elevated serum levels of soluble IL-2 receptors. Neurology 40:215-218

42. Pollard JD, Baverstock J, McLeod JG 1987 Class II antigen expression and inflammatory cells in Guillain-Barré syndrome. Ann Neurol 21:337-341

43. Rostami AM, Eccleston PA, Silberberg DH, Manning MC, Burns JB, Lisak RP 1987 Search for antibodies to galactocerebroside in the sera and cerebrospinal fluid in human demyelinating disorders. Ann Neurol 22:381-383

44. Saida T, Saida K, Lisak RP, Brown MJ, Silberberg DH, Asbury AK 1982 In vivo demyelinating activity of sera from patients with Guillain-Barré syndrome. Ann Neurol 11:69-75

45. Goust JM, Chenais F, Carnes J, Hames CG, Fudenberg HH, Hogan EL 1978 Abnormal $\mathrm{T}$ cell subpopulations and circulating immune complexes in Guillain-Barré syndrome and multiple sclerosis. Neurology 28:421-425

46. Koski CL, Gratz E, Sutherland J, Mayer RF 1986 Clinical correlation with antiperipheral myelin antibodies in Guillain-Barré syndrome. Ann Neurol 19:573-577

47. Koski CL 1990 Characterization of complement-fixing antibodies to peripheral nerve myelin in Guillain-Barré syndrome. Ann Neurol 27(suppl):S44-S47

48. Ilyas AA, Willison HJ, Quarles RH, Jungalwala FB, Cornblath DR, Trapp BD Griffin DE, Griffin JW, McKhann GM 1988 Serum antibodies to gangliosides in Guillain-Barré syndrome. Ann Neurol 23:440-447

49. Yu R, Ariga T, Kohriyama T, Kusunoki S, Maeda Y, Miyatani N 1990 Autoimmune mechanisms in peripheral neuropathies. Ann Neurol 27(suppl):S30-S35

50. Ropper AH Shahani BT 1984 Diagnosis and management of acute areflexic paralysis with emphasis on Guillain-Barré syndrome. In: Asbury K, Gilliatt R (eds) Peripheral Nerve Disorders, A Practical Approach, Vol 2. Butterworths, Boston, pp 21-45

51. The Guillain-Barré Syndrome Study Group 1985 Plasmapheresis and acute Guillain-Barré syndrome. Neurology 35:1096-1104

52. Hughes RAC, Newson-Davis CJ, Perkins GD, Pierce JM 1978 Controlled tria of prednisone in acute polyneuropathy. Lancet 2:750-753

53. Surik HM, McQuillen MP 1976 The use of steroids in the treatment of idiopathic polyneuritis. Neurology 25:205-212

54. Pollard JD 1987 A critical review of therapies in acute and chronic inflammatory demyelinating polyneuropathies. Muscle Nerve 10:214-221

55. van der Meché FGA, Schmitz PIM, the Dutch Guillain-Barré Study Group 1992 A randomized trial comparing intravenous immune globulin and plasma exchange in Guillain-Barré syndrome. N Engl J Med 326:1123-1129

56. Dyck PJ, Lais AC, Ohta M, Bastron JA, Okazaki H, Groover RL 1975 Chronic inflammatory polyradiculoneuropathy. Mayo Clin Proc 50:621-627

57. Barohn RJ, Kissel JT, Warmolts JR, Mendell JR 1989 Chronic inflammatory demyelinating polyradiculoneuropathy. Arch Neurol 46:878-884

58. Pollard JD, McCombe PA, Baverstock J, Gatenby PA, McLeod JG 1986 Class II antigen expression and $\mathrm{T}$ lymphocyte subsets in chronic inflammatory demyelinating polyneuropathy. J Neuroimmunol 13:123-134

59. Lisak RP, Brown MJ 1987 Acquired demyelinating polyneuropathies. Semin Neurol 7:40-48

60. Dyck PJ, Daube J, O'Brien P, Pineda A, Low PA, Windebank AJ, Swanson C 1986 Plasma exchange in chronic inflammatory demyelinating polyradiculoneuropathy. N Engl J Med 314:461-465

61. Vermeulen M, van Der Meché FGA, Speelman JD, Weber A, Busch HFM 1985 Plasma and gamma globulin infusion in chronic inflammatory polyneuropathy. J Neurol Sci 70:317-326

62. Latov N 1987 Peripheral neuropathy and IgM monoclonal gammopathy. In: Aarli JA, Behan WMH, Behan, PO (eds) Clinical Neuroimmunology. Blackwell, Oxford, UK, pp 214-224

63. Steck AJ, Murray N, Dellagi K, Brouet JC, Seligmann M 1987 Peripheral neuropathy associated with monoclonal IgM autoantibody. Ann Neurol 22:764-767

64. Bardwick PA, Zvaifler WJ, Gill GN, Newman D, Greenway GD, Resnick DL 1980 Plasma cell dyscrasia with polyneuropathy, organomegaly, endocrinopathy, M-protein, and skin changes: the POEMS syndrome. Medicine $59: 311-322$

65. Latov N, Hays AP, Donofio PD, Liao J, Ito H, McGinnis S, Manoussos K, Freddo L, Shy ME, Sherman WH, Chang HW, Greenberg HS, Albers JW, Alessi AG, Keren D, Yu RK, Rowland LP, Kabat EA 1988 Monoclonal IgM with unique specificity to gangliosides GMI and GDIb and to lacto-Ntetrose association with human motor neuron disease. Neurology 38:763768

66. Shy ME, Heiman-Patterson T, Parry GJ, Tahmoush AJ, Evans VA, Schick PK 1988 Motor neuropathy in a patient with autoantibodies against ganglio- 
sides GM1 and GDIb: improvement following immunotherapy. Neurology 38(suppl 1):252(abstr)

67. Cornblath DR, McArthur JC, Kennedy PGE, Witte AS, Griffin JW 1987 Inflammatory demyelinating peripheral neuropathies associated with human T-cell lymphotrophic virus type III (HIV) infection. Ann Neurol 21:32-40

68. Vallat JM, Hugon J, Lubeau M, Leboutet MJ, Dumas M, Desprogres-Gotteron R 1987 Tick-bite meningoradiculoneuritis: clinical electrophysiologic and histologic findings in 10 cases. Neurology 37:749-753

69. Halperin JJ, Little BW, Coyle PK, Dattwyler RJ 1987 Lyme disease: cause of a treatable peripheral neuropathy. Neurology 37:1700-1706

70. Hartung HP, Heininger K, Schafer B, Fierz W, Toyka KV 1988 Immune mechanisms in inflammatory polyneuropathy. Ann NY Acad Sci 540:122161

\section{FLOOR DISCUSSION}

Dr. Frank: As was mentioned during the talks, several authors have shown that there are high levels of antibody to myelin in patients with GBS. What was not mentioned was that in studies done in our laboratory with Lee Koski and Moon Chen we also showed very high levels of membrane attack complex in most of those patients. We published one paper in the Journal of Clinical Investigation and two in Blood. We believe the way that IVIG works is that it prevents complement from binding to targets, and this mechanism was not even on your list.

Dr. Rostami: I apologize for that. I was attempting to expedite the presentation.

Dr. Frank: Also, a recent review article in the New England Journal of Medicine doesn't mention high levels of membrane attack complex either. I believe that is a real possibility and certainly worth further consideration.

Dr. Rostami: Absolutely.

Dr. Roifman: You keep saying that plasmapheresis is effective in Guillain-Barré, but in fact the multicenter studies showed almost no effect of plasmapheresis. At best, the results were marginal, maybe a difference of a few days under a respirator. That is an important issue because if plasmapheresis is effective, one may postulate that there may be a humoral factor involved. It may be implicated in the pathogenesis of the disease.

Dr. Rostami: Multicenter studies have clearly shown that plasmapheresis is effective. In the American study, with 245 patients (123 in the conventionally treated group and 122 in the plasmapheresis arm), the percentage of patients who improved at least one grade at 1 mo was $59 \%$ in the plasmapheresis group versus $39 \%$ in the group treated conventionally. The French study also showed significant improvement with plasmapheresis compared with the conventional group.

Dr. Roifman: Effective in what? All they've shown are very marginal effects.

Dr. Rostami: I disagree. As I showed in one of my slides, the time to reach one grade improvement was $17 \mathrm{~d}$ versus $34 \mathrm{~d}$ and the duration of intubation decreased significantly, so I think there is enough evidence to show that plasmapheresis is effective. Whether antibody or something else is being removed from the circulation we don't know. It could be cytokines. We cannot rule out the possibility of T cells, because it could be some cytokine that is being removed rather than antibody alone.

Dr. Roifman: You mentioned the Dutch study and its preliminary results. Do we have information as to what type of patients were involved? Are they patients with severe Guillain Barré? That is an important issue as well, because if these patients are assessed 3 or 4 wk out, the milder cases are going to be very hard to assess.

Dr. Rostami: I have spoken to Dr. Franz van der Meché, the principal investigator in the Dutch study. That study was done at nine centers with 150 consecutive patients, and they were randomized. I have seen the manuscript that has been submitted to the New England Journal of Medicine and have no doubt that the study was done correctly. They took patients in the first 2 wk of the disease and followed them for $6 \mathrm{mo}$, comparing IVIG and plasmapheresis. There was 53\% improvement of strength, by one grade or more, with IVIG versus $34 \%$ with plasmapheresis. This study showed that IVIG was better than plasmapheresis, but there are a couple of criticisms of that study. First, more than 150 patients should be studied, at least 245 as in the North American study. Second, the rate of improvement with plasmapheresis was lower in this study than in the American study, which points to the question of whether the plasmapheresis was comparable to that of the American study.

Dr. Siami: I would like to elaborate a little bit about plasma exchange in GBS. The patient should not be able to walk more than $5 \mathrm{~m}$, which indicates relatively severe disease, and the plasmapheresis should be started in the first week or $10 \mathrm{~d}$ to be useful. 